\title{
Pain rehabilitation treatment for women with breast cancer
}

\author{
Tratamento de reabilitação para dor em mulheres com câncer de mama
}

Tatiana de Bem Fretta1, Leonessa Boing ${ }^{1}$, Regina Maldonato Bussmann², Adriana Coutinho de Azevedo Guimarães ${ }^{3}$

DOI 10.5935/2595-0118.20190049

\section{ABSTRACT}

BACKGROUND AND OBJECTIVES: Breast cancer is a public health problem due to its high rates of incidence and mortality, and the presence of pain in the arm and breast is a very frequent symptom in these women. The objective of this study was to organize scientific evidence on rehabilitation treatments for women after breast cancer surgery.

CONTENTS: The search was performed based on the Medline, LILACS, and Scielo database on articles published in the last 10 years, from January 2008 to January 2018. The survey was carried out with the following keywords: "Breast Cancer" and "Upper Limb" and "Pain" and "Rehabilitation". Randomized clinical trials, pilot study, and quasi-experimental study were included. The search totaled 92 articles, of which only seven articles were selected. The visual analog scale was used in most articles.

CONCLUSION: Physiotherapy and physical exercise can benefit women with breast cancer, reducing pain, and increasing the upper limb's functionality, as well as minimize the lymphedema. Keywords: Breast cancer, Pain, Rehabilitation, Upper limb.

\section{RESUMO}

JUSTIFICATIVA E OBJETIVOS: O câncer de mama é um problema de saúde pública devido às altas taxas de incidência e mortalidade, e a presença de dor no braço e na mama é um sintoma de maior frequência nessas mulheres. $\mathrm{O}$ objetivo deste estudo foi organizar as evidências científicas sobre os tratamentos de reabilitação para dor utilizados com mulheres após a cirurgia do câncer de mama.

\footnotetext{
Tatiana de Bem Fretta - Dhttps://orcid.org/0000-0002-9735-3472;

Leonessa Boing - (Dhttps://orcid.org/0000-0003-4978-9703;

Regina Maldonato Bussmann - (Dhttps://orcid.org/0000-0001-8797-4294;

Adriana Coutinho de Azevedo Guimarāes - (Dhttps://orcid.org/0000-0001-5167-2921.

1. Universidade Estadual de Santa Catarina, Mestranda em Ciências do Movimento Humano, Florianópolis, SC, Brasil.

2. Universidade do Sul de Santa Catarina, Departamento de Fisioterapia, Florianópolis, SC, Brasil. 3. Universidade do Estado de Santa Catarina, Departamento de Educação Física e Programa de Pós-Graduaçấo em Ciências do Movimento Humano, Centro de Ciências da Saúde e do Esporte, Florianópolis, SC, Brasil.
}

Submitted on July 25, 2018.

Accepted for publication on January 07, 2019.

Conflict of interests: none - Sponsoring sources: none.

Correspondence to:

Trav. Ademir Guimarăes, 176

88030-420 Florianópolis, SC, Brasil.

E-mail: tatibem@hotmail.com

(C) Sociedade Brasileira para o Estudo da Dor
CONTEÚDO: A busca foi realizada a partir da consulta às bases de dados Pubmed, LILACS e Scielo, dos artigos publicados nos últimos 10 anos, de janeiro de 2008 a janeiro de 2018. O levantamento foi realizado com os seguintes descritores: "Breast Cancer" $A N D$ "Upper Limb" $A N D$ "Pain" $A N D$ "Rehabilitation". Foram incluídos ensaios clínicos randomizados, estudos piloto e estudos quase-experimentais. A busca totalizou 92 artigos e destes foram selecionados apenas sete. A escala analógica visual foi utilizada na maioria dos artigos.

CONCLUSÃO: A fisioterapia e o exercício físico podem beneficiar mulheres com câncer de mama, reduzindo a dor e aumentando a funcionalidade de membro superior, além de minimizar o linfedema.

Descritores: Câncer de mama, Dor, Extremidade superior, Reabilitação.

\section{INTRODUCTION}

Breast cancer (BC) is a public health problem due to the high incidence and mortality rates. Among the types of cancer, breast cancer has the highest incidence among women ${ }^{1,2}$. In the world, the growth rate has reached $20 \%$ in the last decade, and the impact of cancer will correspond to $80 \%$ in the population between developed and developing countries ${ }^{1}$.

BC surgery, axillary lymphadenectomy, and manipulation of the pectoral muscles bring a risk of tissue injury and complications in up to $70 \%$ of cases. Complications due to axillary alterations include chronic pain, shoulder movement limitations, and muscle atrophy ${ }^{3}$.

Thus, the presence of moderate or severe pain is more frequent in patients undergoing axillary dissection compared to those who underwent sentinel node biopsy ${ }^{4}$. The occurrence of pain in the arm that is homolateral to the surgery is more related to the extension of the axillary surgical procedure and injuries to some structures such as the intercostobrachial nerve and the serratus anterior ${ }^{4}$. Arm and breast pain is the most frequent symptom in these women, corresponding to $51.6 \%{ }^{4-6}$. In patients under 40 years old, the presence of lymphedema significantly increases the risk of post-mastectomy pain syndrome $\mathrm{m}^{7}$, and the literature converges on sedentary behavior as a predictor of pain ${ }^{8-10}$. Thus, rehabilitation may be an acceptable non-pharmacological alternative to minimize pain in women with BC to promote an improvement in physical recovery.

Thus, to minimize the pain caused by the treatment of BC, rehabilitation becomes essential and an integral part in the adjunctive treatment of these women. Given the above, this study aimed to organize the scientific evidence on pain rehabilitation treatments used with women after BC surgery. 


\section{CONTENTS}

The systematic review was performed based on a retrospective consultation of the Scielo, Pubmed, and LILACS databases, in January 2018, and the search strategy was formulated by crossing descriptors (DeCS and MeSH). Only studies conducted with women diagnosed with $\mathrm{BC}$ and treated with pain rehabilitation techniques were included. In addition, the studies should be in Portuguese, English, or Spanish, published in the last 10 years (January 2008 to January 2018). Articles that did not present any intervention to treat pain were excluded.

In the Scielo, LILACS (DeCS) and Medline databases, the following crosses were used: "Breast Cancer" AND "Upper Limb" AND "Pain and Rehabilitation". In the initial phase, titles and abstracts were independently identified and assessed by two reviewers to select those that met the eligibility criteria. Articles that did not meet the criteria described were excluded by title analysis, followed by exclusion by the abstract. Finally, potentially relevant studies were retained for further analysis of the full text. The prominent information was presented in a descriptive table, considering the following variables: authors, sample, assessed outcomes, methodological design, intervention, and effects found. In the initial search in the databases, 92 articles were found. After a first selection by title, 75 articles were excluded, staying 17 for analysis of the abstracts. Of these, eight articles were selected that met the inclusion criteria established.

Figure 1 shows the selection process of the included articles, and table 1 shows the list of selected studies that used rehabilitation to treat pain in women with BC.

Analyzing the results obtained by the search strategy, there was a higher concentration of studies in 2016, with a single publication in 2008. It is also evident that the study participants were volunteers of different age groups, but the average age of the analyzed samples corresponded to the middle-age population. Of the eight articles that were used in this study, four used

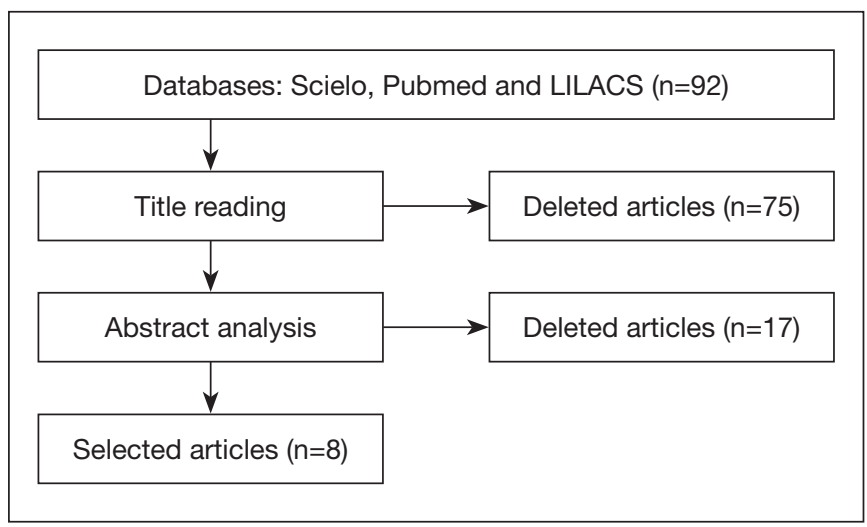

Figure 1. Data Search

Table 1. Description of the selected studies that used rehabilitation to treat pain in women with breast cancer

Authors Sample Assessed outcomes Methodological Intervention Results
design

De Groef 147 women A question regarding Randomized clin- All participants

et al. ${ }^{12}$ in $\mathrm{CG} 53 \pm 9$ the prevalence point ical trial divided years old of pain, shoulder and into 2 groups. and IG 54 7 neck region, arm, CG $(n=74)$. IG $(n=69)$. years old.

armpit, trunk side, and breast region (yes/no).

VAS and McGill pain. DASH upper limb (UL) functionality. QoL SF-36.

Ibrahim et al. ${ }^{8}$

$(n=147)$ four months before randomization received physical therapy. cal therapy and placebo treatment IG received physical therapy and myofascial therapy.

CG $(n=30)$ received standard care (gen-
59 women aged 39.2 \pm 5.0 years old.
General information ROM was used the goniometer for flexion, abduction, adduction, ER and IR movements.

Presence of pain (yes/no) during isolated movements. Wrist strength was measured using a hand dynamometer.
All patients were assessed before surgery and at 2, 4, 9, and 12 months after surgery.

Prospective randomized study. 6 assessments (T1) after surgery and before radiotherapy, (T2) after radiotherapy completion, (T3) 3 months, (T4) 6 months, (T5) 12 months and (T6) 18 months after radiotherapy. CG received physieral information and encouragement of a healthy lifestyle with physical exercise). IG (n=29) 12-week levels were decreased in IG for flexion, exercise program abduction, and ER movements and inthat began in the creased incidence of pain in the same first three to four movements in CG.

weeks after radio- T5-T6 12 months after radiotherapy IG therapy. did not report pain in all movements except for ER. Recurrence of IG pain at 18 months after radiotherapy was present in all shoulder movements. In contrast, CG at 12 months after radiation reported pain in all movements and persisted at 18 months after radiotherapy in flexion and ER movements. 
Table 1. Description of the selected studies that used rehabilitation to treat pain in women with breast cancer - continuation

\begin{tabular}{|c|c|c|c|c|c|}
\hline Authors & Sample & Assessed outcomes & $\begin{array}{l}\text { Methodological } \\
\text { design }\end{array}$ & Intervention & Results \\
\hline $\begin{array}{l}\text { House et } \\
\text { al. }^{13}\end{array}$ & $\begin{array}{lr}6 & \text { women } \\
\text { aged } 57 \pm 8 \\
\text { years old. }\end{array}$ & $\begin{array}{l}\text { Pain assessed by NRS. } \\
\text { UL, FMA, and CAH- } \\
\text { Al-9 function. } \\
\text { JHFT hand function. } \\
\text { BDI } \\
\text { Dynamometer hand } \\
\text { strength. } \\
\text { Wrist weights strength. }\end{array}$ & Pilot study & $\begin{array}{l}\text { Twice a week training } \\
\text { for eight weeks with } \\
\text { robotic rehabilitation, } \\
\text { each session lasted } \\
20 \text { to } 50 \text { minutes. }\end{array}$ & $\begin{array}{l}\text { The pain was measured at the beginning } \\
\text { and end of each session, with a } 20 \% \text { de- } \\
\text { crease in reported severity. } \\
\text { UL movements improved ( } p=0.02 \text { ). } \\
\text { The BDI scale results were statistically sig- } \\
\text { nificant after training ( } p=0.01) \text {. }\end{array}$ \\
\hline $\begin{array}{l}\text { Cho et } \\
\text { al. } .^{14}\end{array}$ & $\begin{array}{l}48 \text { women } \\
\text { aged } 50 \pm 7 \\
\text { years old in } \\
\text { the physical } \\
\text { therapy group } \\
\text { (PT) and } 46 \pm 6 \\
\text { years old in the } \\
\text { physical thera- } \\
\text { py combined } \\
\text { with manual } \\
\text { lymphatic drai- } \\
\text { nage (PTMLD) } \\
\text { group. }\end{array}$ & $\begin{array}{l}\text { Assessment of peri- } \\
\text { metry lymphedema. } \\
\text { Manual dynamometer } \\
\text { force. } \\
\text { Digital inclinometer } \\
\text { shoulder ROM. } \\
\text { QL EORT QLQ-C30. } \\
\text { DASH functionality. } \\
\text { Visible and palpable } \\
\text { presence of the axil- } \\
\text { lary cord. }\end{array}$ & Randomized & $\begin{array}{l}\text { Two groups, one PT } \\
(n=24) \text { and another } \\
\text { PTMLD group ( } n=24) \text {. } \\
\text { Three times a week } \\
\text { for four weeks. }\end{array}$ & $\begin{array}{l}\text { In both groups, there was a significant im- } \\
\text { provement in physical, emotional, and so- } \\
\text { cial role, fatigue, and pain }(p<0.05) \text {. Arm vo- } \\
\text { lume increased significantly over time in the } \\
\text { PT group ( }<<0.05) \text {. The PTMLD group sig- } \\
\text { nificantly decreased the NRS score com- } \\
\text { pared to the PT group }(p<0.05) \text {. The same } \\
\text { occurred based on the EORT QLQ-C30. } \\
\text { The pain was also significantly decreased } \\
\text { in the PTMLD group compared to the PT } \\
\text { group ( } p<0.05) \text {. Significant decrease in arm } \\
\text { volume was observed in the PTMLD group } \\
(p<0.05) \text {. }\end{array}$ \\
\hline $\begin{array}{l}\text { Zengin } \\
\text { Alpozgen } \\
\text { et al. }{ }^{9}\end{array}$ & $\begin{array}{l}57 \text { wo- } \\
\text { men aged } \\
46.22 \pm 11.19 \\
\text { years old in } \\
\text { the Pilates } \\
\text { group (PE), } \\
51.94 \pm 8.05 \\
\text { in the exer- } \\
\text { cise group } \\
\text { (CE) and } \\
51.53 \pm 13.81 \\
\text { in the ho- } \\
\text { me-exercise } \\
\text { group (HE). }\end{array}$ & $\begin{array}{l}\text { Pain assessed by VAS. } \\
\text { Digital goniometer } \\
\text { shoulder ROM. } \\
\text { Force digital dynamo- } \\
\text { meter. } \\
\text { UL DASH and Cons- } \\
\text { tant-Murley Functio- } \\
\text { nality. }\end{array}$ & Randomized & $\begin{array}{l}\text { Three groups: PE } \\
(\mathrm{n}=18) \text {, Stretching, } \\
\text { strengthening, and } \\
\text { shoulder range of } \\
\text { motion }(C E) \text { exercise } \\
\text { group ( } \mathrm{n}=18) \text { and the } \\
\text { home exercise (HE) } \\
\text { group }(\mathrm{n}=19) . \mathrm{PE} \text { and } \\
\text { EC groups were su- } \\
\text { pervised by a physi- } \\
\text { cal therapist three ti- } \\
\text { mes a week for eight } \\
\text { weeks. }\end{array}$ & $\begin{array}{l}\text { Pain on movement decreased significantly } \\
\text { in all groups }(p<0.001) \text {. Resting pain also } \\
\text { improved significantly in all } P E(p=0.004) \text {, } \\
C E(p=0.002) \text {, and } H E(p=0.005) \text { groups. } \\
\text { Muscle strength increased in the PE and } \\
\text { CE groups. } \\
\text { In ROM, the CE group had an improvement } \\
\text { in all shoulder movements }(p<0.001) \text {, in the } \\
P E \text { group only in shoulder flexion ( } p=0.001) \\
\text { and shoulder abduction movements } \\
\text { ( } p=0.002) \text { and in the HE group only. In } \\
\text { shoulder abduction movement ( } p=0.002) \text {. } \\
\text { There was a significant improvement in } \\
\text { UL functionality for } P E \text { and CE groups } \\
\text { ( } p<0.001) \text {. }\end{array}$ \\
\hline $\begin{array}{l}\text { Angooti } \\
\text { Oshnari } \\
\text { et al. }{ }^{15}\end{array}$ & $\begin{array}{l}36 \text { women } \\
\text { aged } \\
53 \pm 10.28 \\
\text { years old }\end{array}$ & $\begin{array}{l}\text { Arm volume was cal- } \\
\text { culated as arm per- } \\
\text { centage volume re- } \\
\text { duction (PVR) } \\
\text { VAS pain }\end{array}$ & $\begin{array}{l}\text { Quasi-experi- } \\
\text { mental study. }\end{array}$ & $\begin{array}{l}1^{\text {st }} \text { phase - six times a } \\
\text { week for two weeks, } \\
\text { it was performed by } \\
\text { manual lymphatic } \\
\text { drainage (MLD) phy- } \\
\text { sical therapist. } \\
2^{\text {nd }} \text { phase - mainte- } \\
\text { nance, for two weeks } \\
\text { included daily lym- } \\
\text { phatic drainage per- } \\
\text { formed by the patient } \\
\text { (SLD) with monitoring } \\
\text { of the physical thera- } \\
\text { pist twice a week }\end{array}$ & $\begin{array}{l}\text { Lymphatic drainage was effective in redu- } \\
\text { cing lymphatic edema and pain in women } \\
\text { after breast cancer surgery. }\end{array}$ \\
\hline $\begin{array}{l}\text { Rett et } \\
\text { al. }{ }^{16}\end{array}$ & $\begin{array}{l}39 \text { women } \\
\text { aged } \\
50.6 \pm 10.8 \\
\text { years old }\end{array}$ & $\begin{array}{l}\text { ROM by Goniometry. } \\
\text { VAS - intensity of pain. } \\
\text { McGill (Br-MPQ) pain } \\
\text { characterization. }\end{array}$ & $\begin{array}{l}\text { Descriptive and } \\
\text { lo n g it u d in a I } \\
\text { analytical study. }\end{array}$ & $\begin{array}{l}\text { There were } 20 \text { physi- } \\
\text { cal therapy sessions, } \\
3 \text { times a week, las- } \\
\text { ting } 60 \text { minutes. The } \\
\text { exercises were cer- } \\
\text { vical stretching and } \\
\text { active-free exercises } \\
\text { of flexion, extension, } \\
\text { abduction, adduc- } \\
\text { tion, IR, and ER. }\end{array}$ & $\begin{array}{l}\text { VAS pain decreased from } 3.8 \pm 1.7 \text { to } \\
3.0 \pm 1.9 \text { when compared from the } 1^{\text {st }} \text { ses- } \\
\text { sion to the } 10^{\text {th }} \text { session. From the } 1^{\text {st }} \text { ses- } \\
\text { sion to the } 20^{\text {th }} \text { session, there was no de- } \\
\text { crease in pain }(p=0.09) \text {, and from the } 10^{\text {th }} \\
\text { session to the } 20^{\text {th }} \text { session }(p=0.79 \text { ). } \\
\text { In the } B r-M P Q \text { scale from the } 1^{\text {st }} \text { session } \\
\left.(p=0.0021) \text { and the } 10^{\text {th }} \text { session ( } p=0.0159\right) \\
\text { and from the } 1^{\text {st }}(p=0.0001 \text { ) session to the } \\
20^{\text {th }}(p=0.0003) \text {. } \\
\text { ROM improved in all movements, and no } \\
\text { association was found between ROM and } \\
\text { pain intensity. }\end{array}$ \\
\hline
\end{tabular}


Table 1. Description of the selected studies that used rehabilitation to treat pain in women with breast cancer - continuation

\begin{tabular}{|c|c|c|c|c|c|}
\hline Authors & Sample & Assessed outcomes & $\begin{array}{l}\text { Methodological } \\
\text { design }\end{array}$ & Intervention & Results \\
\hline $\begin{array}{l}\text { Keays et } \\
\text { al. }^{10}\end{array}$ & 4 women & $\begin{array}{l}\text { ROM by Goniometry. } \\
\text { UL functionality sel- } \\
\text { f-reported 12-item } \\
\text { questionnaire. } \\
\text { Pain - BPI } \\
\text { Humor - (POMS) } \\
\text { Lymphedema - Peri- } \\
\text { metry }\end{array}$ & Not shown & $\begin{array}{l}\text { Pilates specific exer- } \\
\text { cises for } 12 \text { weeks, } \\
\text { three times a week. }\end{array}$ & $\begin{array}{l}\text { All women improved shoulder flexion and ER, } \\
\text { and } 2 \text { women improved abduction and RI. } \\
3 \text { women had zero pain score. } \\
3 \text { women showed improved mood. } \\
\text { In the analysis of UL functionality, } 2 \text { women } \\
\text { reported improvement, and only } 1 \text { woman } \\
\text { kept UL functionality stable. }\end{array}$ \\
\hline
\end{tabular}

$\overline{\mathrm{VAS}}$ = visual analog scale; QoL = quality of life; ER = external rotation; IR = internal rotation; Br-MPQ = McGill Pain Questionaire; BPI = Brief Pain Inventory Short; DASH = Disabilities of the Arm, Shoulder and Hand; ROM = range of motion; NRS = Numeric Rating Scale; FMA = Fugl-Meyer Assessment; CAHAI-9 = Chedoke arm and hand activity inventory; JHFT = Jebsen-Taylor Hand Function Test; UL = upper limb; BDI = Beck Depression Inventory; EORTC QLQ-C30; European Organization for Research and Treatment of Cancer Quality of Life Questionnaire C30; POMS = Profile of Mood States.

VAS to assess pain, two articles were assessed by the McGill pain scale, and one article was assessed by the Brief Pain Inventory Short (BPI). VAS is a one-dimensional measure for pain intensity assessment. Composed of a $10 \mathrm{BC}$ line, with anchors at both ends, on one end of the line is marked "no pain" and the other "worst pain imaginable." The magnitude of pain is indicated by marking the line, and a ruler is used to quantify the measurement on a scale from zero to $100 \mathrm{~mm}^{11}$. It is recognized worldwide and widely used in studies with BC patients.

\section{DISCUSSION}

$\mathrm{BC}$ is the most common among women, causing upper limb disability homolateral to surgery and chronic pain, being observed in the listed studies. Decreased upper limb functionality homolaterally to surgery may interfere with the quality of life of these women, and the prevalence of pain is high as a result of treatment. This study revealed effective outcomes regarding pain relief rehabilitation in women with BC.

The interaction of psychological and social factors, surgery, upper limb muscle weakness homolateral to the surgery, decreased range of motion (ROM) and pain are determinant to cause reduced upper limb functionality. Impaired functionality negatively affects the QoL of these women. Studies by Ibrahim et al. ${ }^{8}$, Zengin Alpozgen et al. ${ }^{9}$ and Keays et al. ${ }^{10}$ reported that physical exercise was able to promote the improvement of clinical symptoms related to pain. In addition, physical exercise improves joint mobility, upper limb functionality, and increased muscle strength ${ }^{8-10}$. The duration of pain treatment in these women can be from 4 to 12 weeks. However, some authors suggest the need to treat this symptom for a longer period of time ${ }^{8-10}$.

In the specific exercise program, Ibrahim et al. ${ }^{8}$ were able to improve shoulder ROM three months after radiation compared to the control group, and it was found that increased ROM is associated with a reduction in the incidence of pain. Participants had pain in all shoulder movements at 12 months after radiation. However, there was a decrease in pain in the intervention group compared to the control group. On the other hand, shoulder movement pain remained in both groups at 18 months after radiation.
The Pilates method was used in rehabilitation in the studies by Zengin Alpozgen et al. ${ }^{9}$ and Keays et al. ${ }^{10}$. The method has been shown to be adequate and capable of eliminating adverse effects of $\mathrm{BC}$ treatment, relieving or reversing the reduction of shoulder mobility, improving ROM, decreasing pain at movement and at rest, and consequently promoting the improvement of upper limb functionality.

Robotic rehabilitation for eight weeks was used by House et al. ${ }^{13}$. The authors observed improvement in activities of daily living due to increased muscle strength and ROM. Also, the study's most notable finding was a significant improvement in depression. This finding facilitates the hypothesis that the ability to interact with virtual media may be beneficial to the mental health of this population.

The upper trapezius muscle region has been described as one of the most sensitive areas in patients with BC. Pain caused by myofascial dysfunction may, in fact, manifest as increased pressure and hypersensitivity in the upper limb region ${ }^{12}$. Myofascial therapy, however, had no beneficial effects on the prevalence, quality, and intensity of postoperative pain after BC surgery ${ }^{12}$.

It is noteworthy that lymphedema causes pressure on the vessels and peripheral nerves of the skin and muscles of the upper limb and trunk, causing pain. In this context, in studies by Cho et al. ${ }^{14}$ and Angooti Oshnari et al. ${ }^{15}$, lymphatic drainage reduced muscle pain and lymphedema, which is a painful condition that limits upper limb functioning and leads to low QoL ${ }^{14,15}$.

Kinesiotherapy improves the ROM of these women and reduces pain when performed at the beginning of treatment, even without showing a direct relationship between increased $\mathrm{ROM}$ and decreased pain ${ }^{16}$. Knowing the interference in daily life with the physical and social tasks that the pain can lead, it is extremely relevant and valid to think about this strategy within rehabilitation.

Rehabilitation has been shown to be effective in improving pain in patients with BC. From this review, it was noted that several features such as manual therapy, stretching and muscle strengthening exercise, upper limb mobility, lymphatic drainage, and Pilates exercises bring notable benefits for women with $\mathrm{BC}^{8-16}$. 


\section{CONCLUSION}

Physical therapy and physical exercise can benefit patients with $\mathrm{BC}$ by reducing pain and increasing upper limb functionality and improving lymphedema.

\section{REFERENCES}

1. INCA - Instituto Nacional de Câncer José Alencar Gomes da Silva. Coordenaçâo de Prevençăo e Vigilância Estimativa 2018: Incidência de Câncer no Brasil/Instituto Nacional de Câncer José Alencar Gomes da Silva, Coordenaçáo de Prevenção e Vigilância. Rio de Janeiro. http://www2.inca.gov.br:acesso em 17 de março de 2018.

2. GLOBOCAN - Cancer Incidence and Mortality Worldwide: IARC Cancer Base No. 11 [Internet]. Lyon, France: International Agency for Research on Cancer. 2012. Volume 1.1. Disponível em: http://globocan.iarc.fr, acesso em 27 de dezembro de 2017.

3. Gonçalves Ade V, Teixeira LC, Torresan R, Alvarenga C, Cabello C. Randomized clinical trial on the preservation of the medial pectoral nerve following mastectomy due to breast cancer: impact on upper limb rehabilitation. Sao Paulo Med J. 2009;127(3):117-21.

4. Ferreira BP, Pimentel MB, Santos LC, di Flora W, Gobbi H. [Morbidity after sentinel node biopsy and axillary dissection in breast cancer]. Rev Assoc Med Bras. 2008;54(6):517-21. Portuguese.

5. Kopec JA, Colangelo LH, Land SR, Julian TB, Brown AM, Anderson SJ, et al. Relationship between arm morbidity and patient-reported outcomes following surgery in women with node-negative breast cancer: NSABP protocol B-32. J Support Oncol. 2013;11(1):22-30.

6. Sousa E, Carvalho FN, Bergmann A, Fabro EA, Dias RA, Koifman RJ. Funcionalidade de membro superior em mulheres submetidas ao tratamento do câncer de mama. Rev Bras Cancerol. 2013;59(3):409-17.
7. Alves Nogueira Fabro E, Bergmann A, do Amaral e Silva B, Padula Ribeiro AC, de Souza Abrahão K, da Costa Leite Ferreira MG, et al. Post-mastectomy pain syndrome: incidence and risks. Breast. 2012;21(3):321-5.

8. Ibrahim M, Muanza T, Smirnow N, Sateren W, Fournier B, Kavan P, et al. A pilot randomized controlled trial on the effects of a progressive exercise program on the range of motion and upper extremity grip strength in young adults with breast cancer. Clin Breast Cancer. 2018;18(1):e55-e64.

9. Zengin Alpozgen A, Razak Ozdincler A, Karanlik H, Yaman Agaoglu F, Narin AN. Effectiveness of Pilates-based exercises on upper extremity disorders related with breast cancer treatment. Eur J Cancer Care. 2017;26(6):1-8.

10. Keays KS, Harris SR, Lucyshyn JM, MacIntyre DL. Effects of Pilates exercises on shoulder range of motion, pain, moos, and upper-extremity function in women living with breast cancer: a pilot study. Phys Ther. 2008;88(4):494-510.

11. Price DD, McGrath PA, Rafii A, Buckingham B. The validation of visual analogue scales as ratio scale measures for chronic and experimental pain. Pain. 1983;17(1):45-56.

12. De Groef A, Meeus M, De Vrieze T, Vos L, Van Kampen M, Christiaens MR, et al Pain characteristics as important contributing factors to upper limb dysfunctions in breast cancer survivors at long term. Musculoskelet Sci Pract. 2017;29:52-9.

13. House G, Burdea G, Grampurohit N, Polistico K, Roll D, Damiani F, et al. A feasibility study to determine the benefits of upper extremity virtual rehabilitation therapy for coping with chronic pain post-cancer surgery. Br J Pain. 2016;10(4):186-97.

14. Cho Y, Do J, Jung S, Kwon O, Jeon JY. Effects of a physical therapy program combined with manual lymphatic drainage on shoulder function, quality of life, lymphedema incidence, and pain in breast cancer patients with axillary web syndrome following axillary dissection. Support Care Cancer. 2016;24(5):2047-57.

15. Angooti Oshnari L, Hosseini SA, Haghighat S, Hossein Zadeh S. The effect of complete decongestive therapy on edema volume reduction and pain in women with post breast surgery lymph edema. Iran J Cancer Prev. 2016;9(2):e4209.

16. Rett MT, Mesquita PJ, Mendonça AR, Moura PD, DeSantana JM. A cinesioterapia reduz a dor no membro superior de mulheres submetidas à mastectomia ou quadrantectomia. Rev Dor. 2012;13(3):201-7. 